\title{
Pengaruh faktor - faktor terhadap Pendapatan Pedagang Kaki Lima Di Grogol Jakarta Barat \\ Ade Onny Siagian
}

Universitas Bina Sarana Informatika,Jakarta, Indonesia

Corresponding Author: $\otimes$ ade.aoy@bsi.ac.id

\section{ABSTRACT}

The income of street vendors can be relied on by several factors. This research was conducted to determine the extent of the influence of the factors of capital, length of work, working hours, and labor on the income of street vendors in Grogol, West Jakarta City, either simultaneously or partially. This study uses primary data. using the Slovin method as many as 82 respondents. Multiple linear regression analysis techniques. The results show the fact that respondents based on the income of street vendors in Grogol with an average income of $\leq$ $1,000,000$, based on the capital of street vendors in Grogol with an average of 2,100,000 -3,000,000, based on the length of business of the street vendors. in Grogol it is 6 - 10 years, based on the working hours of street vendors in Grogol of 7 - 9 hours, based on the workforce of street vendors in Grogol of 1 - 2 people. Regression results with a significant level of $5 \%$ partially. Simultaneously, the factors of capital, length of business, working hours, and labor together can affect the income of street vendors in Grogol, West Jakarta. While the value of the coefficient of determination is $73.4502 \%$ which can serve by the independent variables in the model.

Keywords

Income, Capital, Length of Business, Hours of Work,

\section{PENDAHULUAN}

Akibat dari prosesnya globalisasi serta liberalisasi perdagangan dunia sudah melajukan terbentuknya perubahan-perubahan yang ekstrem kepada area bisnis.ikatan antar negara dan bangsa menjadi tidak memahami batasbatas teritorial, baik dalam segi investasi ataupun industri serta pula informasi. Tidak hanya itu seluruh penghalang pada terbentuknya lalu lintas perdagangan antar suatu negara telah dimudahkan.Dalam suasana ini maka persaingan bisnis ini menjadi lepas kendali serta diketahui sebagai istilah hypercompetition (D'Aveni dalam Asakdyah, 2004). Manusia dalam memenuhi kebutuhan setiap hari, manusia bersaing dan berjuang untuk tetap bertahan hidup serta menanggulangi masalahnya dengan menggunakan sumber energi alam, tenaga dan pikiran yang dimilikinya, dan tersedianya modal yang terdapat pada diri dan lini Pembangunan ekonomi yang dilakukan oleh Negara yang lagi berkambang dalam rangka tingkatanaktivitas ekonomi taraf hidup rakatnya yang bertujuan untuk tingkatkan kesejahteraan warga. Kesusahan yang kerap terjadi dialami merupakan permasalahan ketenagakerjaan, dalam 
perihal ini merupakan meningkatnya jumlah pengangguran, sebab tidak seluruh penduduk bisa menawarkan tenaga kerja yang dimilikinya. Tidak hanya itu terus berkurangnya sektor formal dalam meresap tenaga kerja. Sehingga lebih memilah bekerja di zonainformal. Pedagang Kaki Lima (PKL) ialah salah satu wujud kegiatan perdagangan pada zona informal.PKL pada rata-ratanya merupakan pedagang kecil yang berfungsi sebagai penyalur suatu barang dan jasa ekonomi kota. Dari penafsiran tersebut, bisa didefinisikan bahwa PKL merupakan seseorang yang melaksanakan aktifitas usaha perdagangan ataupun jasa, yang dilakukan tertuju pada berpindah-pindahnya tempat dengan keahlian modal yang kecil ataupun terbatas, dalam melaksanakan usaha tersebut hanya memakai perlengkapan simple ataupun seadanya yang pedagang miliki jika sedikitnya suatu modal yang terutama dia dapat mulai berdagang serta memakai fasilitas-fasilitas universal untuk berdagang, dan tidak mempunyai legalitas formal. Faktor-faktor yang pengaruhi pemasukan pedagang kaki lima, antara lain modal, lama usaha, jam kerja, dantenaga kerja. Modal merupakan salah satu aspek yang jadi hambatan utama berdirinya usaha kecil. Hasil riset Wicaksono (2011) berkata, faktor modal seringkali memberikan pengaruh yang besar terhadap suatu usaha dagang, dimana dapat berdampak pada timbulnya permasalahan lain, seperti modal yang dimiliki seadanya, maka seseorang hanya mampu membuka usaha dagangnya tanpa bisa memaksimalkan skala usahanya. Aspek yang kedua ialah lama usaha, dalam usaha semacam riset yang dicoba oleh sunaryanto (2005) berkata, bahwa lamanya seseorang pedagang menekuni usahanya maka akan meningkat pula pengetahuannya dan akan berpengaruh pada tingkat pendapatannya. Menurut hasil riset Wicaksono (2011) berkata faktor jam kerja di dalam suatu usaha memiliki hubungan langsung dengan pendapatan dimana setiap penambahan waktu operasional yang dipengaruhi jumlah hasil produksi. Tenaga kerja pula termasuk faktor produksi yang penting dan harus diperhitungkan dalam proses produksi dengan jumlah yang cukup, tidak hanya dalam perihal jumlah tetapi juga dalam perihal mutu serta macammacam tenaga kerja yang disesuaikan. Jumlah tenaga kerja yang dibutuhkan disesuaikan dengankebutuhan pada tingkatan tertentu sehingga jumlahnya optimum (Soekartawi dalam Dewi, 2014).

\section{METODE PENELITIAN}

Tipe tata cara yang digunakan merupakan analisis deskriptif serta analisis kuantitatif.Analisis deskriptif digunakan bertujuan untuk membagikan uraian serta intrepretasi data serta informasi pada tabulasi data. Analisis kuantitatif bertujuan untuk mengenali faktor yang pengaruhi pemasukan para 
pedagang kaki limaGrogol Jakarta Barat, sehingga digunakan model regresi linier berganda (multiple regression). Perihal ini disebabkan dalam riset ini pemakaian variabel lebih dari satu (multivariabels), sehingga dapat diformulasikan dengan model persamaan regresi sebagai berikut:

$$
\begin{aligned}
& \text { Rumus: } \mathrm{Y}=\alpha+\beta 1 \mathrm{X} 1+\beta 2 \mathrm{X} 2+\beta 3 \mathrm{X} 3+\beta 4 \mathrm{X} 4+\ldots \\
& \text { Keterangan: } \\
& \mathrm{Y}=\text { Pendapatan } \\
& \mathrm{A}=\text { Konstanta } \\
& \beta 1+\beta 2+\beta 3+\beta 4=\text { KoefisienRegresi } \\
& \mathrm{X} 1=\text { Modal Usaha(Rp) } \\
& \mathrm{X} 2=\text { Lama Usaha(Tahun) } \\
& \mathrm{X} 3=\text { Jumlah Jam Kerja (Jam) } \\
& \mathrm{X} 4=\text { Tenaga Kerja(Orang) } \\
& \mathrm{e}=\text { ErrorTerm }
\end{aligned}
$$$$
\beta n X n+e
$$

\section{HASIL DAN PEMBAHASAN}

\section{Regresi Linier Berganda}

Hasil pengolahan data dilakukan dengan menggunakan software Eviews 9 dan dapat diperoleh hasil sebagai berikut:

Tabel 4.1

\section{Hasil Regresi Linear Berganda}

Variable Coefficint Std. Error t-Statistic Prob.

\begin{tabular}{ccccc}
\hline \hline & & & & \\
C & -339653.5 & 161410.1 & -2.104288 & 0.0386 \\
M & 0.096371 & 0.027601 & 3.491532 & $\mathbf{0 . 0 0 0 8}$ \\
LU & 22174.65 & 7196.608 & 3.081264 & $\mathbf{0 . 0 0 2 9}$ \\
JK & 19454.88 & 14754.70 & 1.318554 & 0.1912 \\
TK & 306010.0 & 33253.98 & 9.202208 & $\mathbf{0 . 0 0 0 0}$
\end{tabular}

$$
\mathrm{Y}=-339653.5+0.096371 \mathrm{M}+22174.65 \mathrm{LU}+19454.88 \mathrm{JK}+306010.0 \mathrm{TK}+\mathrm{e}
$$

Keterangan:

$$
\begin{array}{ll}
\text { Y = Pendapatan (Rupiah) } & \text { M= Modal (Rp) } \\
\text { LU= Lama Usaha (Tahun) } & \text { TK = Tenaga Kerja (Orang) } \\
\text { JK = Jam Kerja (jam) } &
\end{array}
$$

\section{Uji t}

Uji $t$ adalah uji semua koefisien regresi secara individual yang bertujuan untuk mengetahui besarnya pengaruh dari masing- masing variabel 
independen terhadap variabel dependennya. Pengujian koefisien regresi secara individual (uji t) dilihat dari signikansi t-statistik. Uji t bertujuan untuk melihat signifikansi pengaruh variable independent terhadap variable dependen secara individual. Hasil pengujian statistic uji t (uji parsial) dapat ditunjukkan sebagai berikut.

1. Pengaruh modal pada pendapatan pedagang kaki lima di Grogol Jakarta Barat. Hasil estimasi menunjukkan bahwa modal (M) memiliki t-stat $>\mathrm{t}-$ tabel atau (3.491532>1.99125) dengan menggunakan derajat keyakinan 95\% (a) $0,05 \%$ dan derajat kebebasan $n-k=82-5=77$, menunjukkan bahwa Ho ditolak dan $\mathrm{H1}$ diterima, yang artinya ada pengaruh yang nyata (signifikan) dari variabel modal secara parsial terhadap pendapatan pedagang kaki lima di Grogol Jakarta Barat.

2. Pengaruh lama usaha pada pendapatan pedagang kaki lima di Grogol Jakarta Barat. Hasil estimasi menunjukkan bahwa lama usaha (LU) memiliki t-stat $>$ t-tabel atau $(3.081264>1.99125)$ dengan menggunakan derajat keyakinan $95 \%$ (a) $0,05 \%$ dan derajat kebebasan $n-k=82-5=77$, menunjukkan bahwa Ho ditolak dan H1 diterima, yang artinya ada pengaruh yang nyata (signifikan) dari variabel lama usaha secara parsial terhadap pendapatanpedagang kaki lima di Grogol Jakarta Barat.

3. Pengaruh jam kerja terhadap pendapatan pedagang kaki lima di Grogol Jakarta Barat. Hasil estimasi menunjukkan bahwa jam kerja (JK) memiliki tstat $>$ t-tabel atau $(1.318554>1.99125)$ dengan menggunakan derajat keyakinan $95 \%$ (a) $0,05 \%$ dan derajat kebebasan $n-k=82-5=77$, menunjukkan bahwa Ho diterima dan H1 ditolak, yang artinya tidak ada pengaruh yang nyata (tidak signifikan) dari variabel jam kerja secara parsial terhadap pendapatan pedagang kaki lima di Grogol Jakarta Barat.

4. Pengaruh tenaga kerja pada pendapatan pedagang kaki lima di Grogol Jakarta Barat. Hasil estimasi menunjukkan bahwa tenaga kerja (TK) memiliki t-stat $>\mathrm{t}$-tabel atau $(9.202208>1.99125)$ dengan menggunakan derajat keyakinan 95\% (a) 0,05\% dan derajat kebebasan n-k $=82-5=77$, menunjukkan bahwa Ho ditolak dan H1 diterima, yang artinya ada pengaruh yang nyata (signifikan) dari variabel tenaga kerja secara parsial terhadap pendapatan pedagang kaki lima di Grogol Jakarta Barat.

\section{Uji F}

Uji F digunakan untuk menunjukkan apakah variabel-variabel independen yang digunakan berpengaruh pada variabel dependen secara keseluruhan. Apabila nilai F-hitung lebih besar dari F-tabel atau probabilitas F lebih kecil dari 5 persen $(\alpha=5 \%)$. Maka variabel-variabel independen secara 
bersama-sama mempengaruhi variabel dependen. Hasil menunjukkan bahwa nilai F-stat lebih besar dari F-tabel atau $53.25516>2,49$, sehingga dapat disimpulkan bahwa variabel bebas yaitu modal, lama usaha, jam kerja, dan tenaga kerja secara bersama-sama mempengaruhi pendapatan pedagang kaki lima di Grogol Jakarta Barat.

Koefisien Determinasi (R2)

Nilai koefisien determinasi (R2) menggambarkan kemampuan model regresi dalam menjelaskan variabel dependen.Nilai koefisien determinasi adalah nol dan satu.Semakin besar nilai R2 maka variabel-variabel independen memberikan hampir semua informasi yang dibutuhkan untuk memprediksi variasi variabel dependen. Berdasarkan hasil estimasi, besarnya R2 yang diperoleh untuk $\mathrm{Y}$ adalah sebesar 0.734502 artinya variabel pendapatan (Y) dalam model sebesar $73,4502 \%$ dapatdijelaskan oleh variabel-variabel bebas yang ada di dalam model yaitu modal, lama usaha, jam kerja, dan tenaga kerja. Sementara $26,5498 \%$ sisanya dijelaskan oleh variabel-variabel lain yang tidak terdapat dalam model ini dan faktor-faktor lainnya. Sehingga dapat disimpulkan bahwa model ini baik dan dapat menjelaskan permasalahan dari penelitian ini.

\section{Uji Multikolinearitas}

Multikolinearitas adalah hubungan linear antara variabel independen di dalam regres.Oleh karena itu, kita mendeteksi multikolinearitas dengan menguji koefisien korelasi (r) antara variabel independen (Gujarati, 2010). Hasil estimasi dapat dilihat bahwa nilai koefisien korelasi antara masing-masing variabel bebas $<0,8$, maka dapat hasilnya adalah tidak terdapat masalah multikolinearitas.

\section{Uji Heteroskedastisitas}

Heteroskedastisitas adalah situasi penyebaran data yang tidak sama atau tidak samanya variasi sehingga uji signifikansi tidak valid. Heteroskedastisitas terjadi apabila variabel gangguan tidak mempunyai varian yang sama untuk semua observasi. Akibat adanya heteroskedastisitas, penaksir OLS tidak bias tetapi tidak efisien (Gujarati, 2010). Berdasarkan hasil analisis dapat dilihat bahwa nilai chi-square lebih besar dari alpha $(\alpha=5 \%)$. Chi-square sebesar 0,0725> a 0,05. Hal ini menunjukkan bahwa tidak terdapat masalah heteroskedastisitas.

\section{Uji Normalitas}

Uji Normalitas bertujuan untuk menguji apakah dalam model regresi, variabel pengganggu atau residual memiliki distribusi normal. Hasil uji normalitas dengan melihat nilai Jarque-Bera dihitung dengan nilai 
probabilitasnya. Nilai probabilitas JB lebih dari 0,05 atau 5\% yaitu dengan nilai 0,580287. Hal ini menunjukkan bahwa residual berdistribusi normal.

Uji Autokolerasi.

Dari hasil pengujian dengan menggunakan metode Breusch-Godfrey LM (Lagrange Multiplier), nilai prob chi-square lebih besar dari a yaitu 0,5784> 0,05. Dengandemikian berdasarkan uji autokorelasi maka dapat disimpulkan bahwa model regresi tidak mengandung adanya masalah autokorelasi.

a) Pengaruh Modal Pada Penghasilan Pedagang Kaki Lima Di Grogol Jakarta Barat. Hasil analisis menunjukkan bahwa variabel modal berpengaruh signifikan dan positif terhadap penghasilan PKL di Grogol Jakarta Barat. Koefisien variabel modal didapat dari hasil sebesar 0. 096371. Nilai koefisien regresi tersebut membagikan arti bahwa apabila modal bertambah 1. 000. 000 rupiah sehingga penghasilan PKL hendak bertambah sebesar 96. 371 rupiah. Hasil diatas tersebut cocok dengan komentar Boediono( 1992) mengemukakan jika salah satu faktor yang pengaruhi penghasilan merupakan aspek penciptaan yang variabel di dalamnya yaitu modal. Dengan demikian modal untuk pedagang kaki lima di Grogol Jakarta Barat ialah aspek yang memiliki pengaruh besar dalam tiap usaha sebab dengan modal yang besar, sehingga dapat menaikkan alterasi komoditas dagangannya sehingga perihal tersebut mengizinkan para pedagang untuk mendapatkan penghasilan yang lebih besar.

b) Pengaruh Lama Usaha Pada Penghasilan Pedagang Kaki Lima Di Grogol Jakarta Barat. Hasil analisis menampilkan bahwa variabel lama usaha mempengaruhi signifikandan positif terhadap penghasilan PKL di Grogol Jakarta Barat. Koefisien variabel lama usaha diperoleh hasil sebesar 22174. 65. Nilai koefisien regresi tersebut memberikan arti, apabila lama usaha bertambah 1 tahun sehingga penghasilan PKL hendak bertambah sebesar 22. 174, 65 rupiah.

c) Lama pembukaan usaha bisa mempengaruhi pada tingkatan pemasukan, lama seseorang pelaksana bisnis menekuni sesuatu bidang usahanya hendak mempengaruhi produktivitasnya (keterampilan profesionalnya/ keahliannya), sehingga dapat menaikkan efisiensi serta sanggup menekan anggaran penciptaan lebih kecil daripada hasil penjualan. Semakin lama menekuni bidang usaha perdagangan hendak kian tingkatkan pengetahuan tentang selera maupun sikap konsumen( Wicaksono, 2011).

d) Pengaruh Jam Kerja Pada Penghasilan Pedagang Kaki Lima Di Grogol Jakarta Barat. Hasil analisis menampilkan kalau variabel Jam tidak mempengaruhi pada pemasukan PKL di Grogol Jakarta Barat, sebab jam kerjanya nyaris sama antar tiap orang dagang kaki lima. Koefisien variabel 
jam kerja diperoleh hasil sebesar 19454. 88. Jadi bisa disimpulkan kalau jam kerja tidak mempengaruhi kepada pemasukan orang dagang kaki 5 di Grogol Jakarta Barat.

Jadi perihal ini meyakinkan kalau banyaknya jumlah jam kerja tidak pengaruhi besarnya pemasukan orang dagang. Dalam realitas di lapangan, orang dagang yang mempunyai jumlah jam kerja yang lebih banyak tidak senantiasa mempunyai pemasukan yang lebih besar, terdapat halnya semacam jam kerja yang sama namun para orang dagang ini mempunyai pemasukan yang berbeda serta pula di Grogol Jakarta Barat mempunya jam- jam tertentu semacam dari jam 14.00 hingga jam 00.00 itu merupakan waktu dimana senantiasa banyaknya para wisatawan danmasalah mutu dagangan serta produk yang di jual tidak cocok dengan apa yang di mau oleh konsumen sehingga walaupun jam kerja di tambah tidak pengaruhi besarnya pemasukan orang dagang.

Pengaruh Tenaga Kerja Pada Pemasukan Orang dagang Kaki Lima Di Grogol Jakarta Barat. Hasil analisis menampilkan kalau variabel tenaga kerja mempengaruhi signifikan serta positif terhadap pemasukan PKL di Grogol Jakarta Barat. Koefisien variabel tenaga kerja diperoleh hasil sebesar 306010. 0. Nilai koefisien regresi tersebut membagikan arti, bila tenaga kerjameningkat 1 orang hingga pemasukan PKL hendak bertambah sebesar 30.6010 rupiah.

Tenaga kerja bisa pengaruhi pada pemasukan usaha, sebab terus menjadi banyak jumlah tenaga kerja, hingga hendak terus menjadi besar pula output yang diperoleh serta diharapkan bisa tingkatkan pemasukan orang dagang( Soetomo, 1990).

\section{KESIMPULAN}

1. Variabel modal mempunyai yang pengaruh positif serta signifikan pada penghasilan( Y) Pedagang Kaki Lima di Grogol Jakarta Barat. Koefisien regresi yang bertanda positif( 0.0008$)$ atau $<(0.05)$ perihal ini membuktikan kalau modal mempunyai ikatan yang searah dengan penghasilan, maksudnya apabila modal naik hingga penghasilan juga hendak naik, sebab dengan modal yang besar para pedagang kaki lima dapat meningkatkan investasi terhadap benda yang hendak di jualnya, dengan kata lain penghasilan pedagang kaki lima bisa meningkat.

2. Variabel lama usaha pengaruh positif serta signifikan terhadap penghasilan( Y) Pedagang Kaki Lima di Grogol Jakarta Barat. Koefisien regresi yang bertanda positif $(0.0029)$ atau < $(0,05)$ perihal ini membuktikan jika lama usaha mempunyai ikatan yang searah dengan penghasilan, artinya terus menjadi lama menekuni bidang usaha perdagangan hendak kian tingkatkan 
pengetahuan tentang selera maupun prilaku konsumen. Keahlian berdagang kian meningkat serta banyak pula pelanggan yang di bisa sehingga bisa tingkatkan pemasukan.

3. Variabel jam kerja tidak mempengaruhi terhadap penghasilan( Y) Pedagang Kaki Lima di Grogol Jakarta Barat.. Koefisien regresi yang bertanda positif ( 0 . 1912) atau > $(0,05)$ yang artinya jika dengan akumulasi jam kerja tidak pengaruhi besarnya pemasukan orang dagang. perihal ini diakibatkan sebab para pedagang tidak tingkatkan mutu dagangannya serta pula tidak dapat memandang apa yang di butuhkan ataupun di mau oleh para konsumen dan sebab terdapatnya tingkatan keramaian pada jam- jam tertentu.

4. Variabel tenaga kerja pengaruh positif serta signifikan terhadap pemasukan( Y) Pedagang Kaki Lima di Grogol Jakarta Barat.. Koefisien regresi yang bertanda positif( 0.0000$)$ atau $<(0,05)$ perihal ini membuktikan kalau tenaga kerja mempunyai ikatan yang searah dengan pemasukan, artinya dengan bertambahnya tenaga kerja bisa meningkatan efisiensi waktu dalam hal pelayanan yang bisa tingkatkan penghasilan.

5. Secara simultan variabel modal, lama harus, jam kerja, serta tenaga kerja menampilkan bahwa nilai F- stat lebih besar dari F- tabel ataupun 53. 255162, 49 , > 2,49, sehingga bisa disimpulkan kalau variabel bebas ialah modal, lama usaha, jam kerja, serta tenaga kerja secara bersama- sama pengaruhi penghasilan pedagang kaki lima di Grogol Jakarta Barat.

\section{PENGAKUAN/ PENGHARGAAN}

Penulis mengucapkan terima kasih kepada salah satu karyawan di Bursa Efek Jakarta (BEJ) yang telah memberikan dukungan materil dan moril dalam penulisan artikel ini. Kami juga berterima kasih kepada Jurnal JECS yang telah memberikan kesempatan untuk berbagi ilmu.

\section{REFERENCES}

Akhbar Nurseta Priyandika. (2015) “Analisis Pengaruh Jarak, Lama Usaha, Modal, Dan Jam Kerja Terhadap Pendapatan Pedagang Kaki Limakonveksi (Studi Kasus Di Kelurahan Purwodinatan Kota Semarang)". Universitas Diponegoro. Semarang

Fatmawati. (2014). “ Analisis Faktor - Faktor yang Mempengaruhi Pendapatan Pedagang Kaki Lima di Pasar Raya Padang" . Jurnal Ilmiah. Sekolah Tinggi Keguruan dan Ilmu pendidikan (STKIP) PGRI. Sumatra Barat

Forlin Natalia Patty \& Maria Rio Rita, (2018). "Faktor - Faktor yang Mempengaruhi Pendapatan Pedagang Kaki Lima (Studi Empiris PKL di Sepanjang Jalan Jendral Sudirman Salatiga)". Jurnal Ilmiah.

I Komang Adi Antara. (2016). "Beberapa Faktor yang Mempengaruhi 
Pendapatan Pedagang Kaki Lima di Kecamatan Denpasar Barat". Jurnal Ilmiah. Universitas Udayana. Bali

Richard G. Lipsey, Peter O. Steiner, Douglas D. Purvis. (1990). Pengantar Mikroekonomi. Jakarta Riko Gesmani. "Analisis Faktor - Faktor Yang Mempengaruhi Pendapatan Usaha Kecil Di Sektor Perdagangan (Studi Kasus Pada Tiga Pasar Di Kota Nabire)". Jurnal Ilmiah. Universitas Satya Wiyata Mandala.

N Riesmiyantiningtias, AO Siagian, Analisis Laporan Keuangan untuk Menilai Kinerja Keuangan Perusahaan Pada PT. Midi Indonesia TBK, Jurnal Akrab Juara, 5 (4), (2020), hlm.244-254.

Siagian, AO, N Indra, Pengetahuan Akuntansi Usaha Mikro, Kecil dan Menengah (UMKM) untuk Laporan Keuangan, Jurnal Syntax Literate, 4 (12), (2019), hlm.17-35. DOI: http://dx.doi.org/10.36418/syntaxliterate.v4i12.825

Siagian, AO, Pengaruh Dana Pihak Ketiga, Modal Bank, Jumlah Kantor Cabang, Suku Bunga dan Jumlah Uang Beredar Terhadap Pinjaman UMKM Bank BUMN, Journal of Syntax Literate, 5 (5), (2020), hlm.1 -17. DOI: http:/ /dx.doi.org/10.36418/syntax-literate.v5i5.1140

Siagian, AO, Kontribusi Sistem Akuntansi Persediaan dalam Meningkatkan Pengendalian Internal Persediaan, Jurnal Ilmu Sosial, 1 (2), (2020) hlm. 1-6. http://jsss.co.id/index.php/jsss/article/view/12

Siagian, AO, The Relationship of Marketing Managerial Individuality in Facing the Industrial Revolution 4.0, Special in Manufacturing Companies in Central Java, Journal of Syntax Literate, 5 (10), (2020), hlm.980-994. DOI: http:/ / dx.doi.org/10.36418/ syntax-literate.v5i10.1669

Siagian AO, TF Prasetyo, (2020). Strategi Pengembangan Kompetensi Usaha Kecil Menengah di Kabupaten Jombang. Jurnal Akrab Juara 5 (4), 2020, hlm.77-85.

http:/ / www.akrabjuara.com/index.php/akrabjuara/article/view/126 3.

Siagian, AO, Analisis Pengaruh Biaya Tanggung Jawab Sosial Perusahaan, Struktur Modal dan Likuiditas terhadap Profitabilitas pada Perusahaan Pertambangan yang Terdaftar di Bursa Efek Indonesia, (2019) Universitas Sumatera Utara.

Siagian, AO, Analisis Pengaruh Keselamatan Dan Kesehatan Kerja Terhadap Kinerja Karyawan PT. Wijaya Karya (Persero) TBK. At The Nayumi Sam Tower Malang Project, International Journal of Business and Information Technology 1 (1), (2020).

Yandhi Fernando, (2016). "Faktor - Faktor yang Mempengaruhi Pendapatan Pedagang Kaki Lima (Studi Kasus di Pasar Besar Kota Malang” . Jurnal Ilmiah. Universitas Brawijaya. Malang.

Badan Pusat Statistik (BPS) "PDRB Kota Jakarta Barat Atas Harga Konstan Tahun 2014 -2017", BPS. Jakarta Barat

Dinas Koperasi UMKM Perindustrian Perdagangan dan Pertanian Kota Jakarta Barat “Data PKL Tahun (2017)”, Grogol 
Dinas Perdagangan Kota Jakarta Barat “Data Pedagang Kaki Lima Tahun (2017)", Grogol

Insukindro, 1998, Dasar-Dasar Ekonomtrika, Jakarta: Penerbit Erlangga.

Mankiw, N. Gregory. (2012). Pengantar Ekonomi Mikro. Jakarta: Salemba Empats

Nasution, M.Zein (ed), (1987), Sektor Informal di Indonesia : Penyerap Tenaga Kerja, Dokumentasi CSIS, Jakarta.

Samuelson \& Nordhaus. (2003). Ilmu Mikro Ekonomi.. Jakarta

Sugiyono. (2015),Metode Penelitian Kuantitatif Kualitatif dan R\&D, Jakarta: Alfabeta

Yandhi Fernando, (2016). Buku Pedoman Penyusunan Tesis, 2016, Fakultas Ekonomi Universitas Pasundan Bandung: Bandung. 